\title{
Streptimonospora salina gen. nov., sp. nov., a new member of the family Nocardiopsaceae
}

\author{
Xiao-Long Cui, ${ }^{1}$ Pei-Hong Mao, ${ }^{2}$ Min Zeng, ${ }^{3}$ Wen-Jun Li, ${ }^{1}$ Li-Ping Zhang, ${ }^{1}$ \\ Li-Hua $\mathrm{Xu}^{1}$ and Cheng-Lin Jiang ${ }^{1}$
}

Author for correspondence: Cheng-Lin Jiang. Tel: +86871 5034139. Fax: +86 8715173878. e-mail: lihxu@ynu.edu.cn

\footnotetext{
1 Yunnan Institute of Microbiology, Yunnan University, Kunming 650091, Yunnan, China

2 Institute of Microbiology, Xinjiang Agriculture Academy of Sciences, Wulumuqi 830000, Xinjiang, China

3 Food Industry Research \& Development Institute, PO Box 246, Hsinchu, 300 Taiwan, China
}

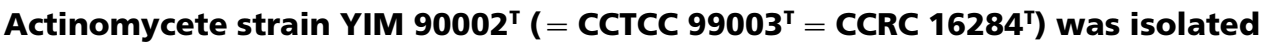
from a soil sample collected from a salt lake in the west of China. The aerial mycelium of this organism is well developed but not fragmented and, at maturity, forms short chains of spores. Spores in short chains are oval- to rodshaped and have wrinkled surfaces. Substrate mycelium is branched with nonfragmenting hyphae and forms single oval to round spores borne on sporophores or dichotomously branching sporophores. Single spores have wrinkled surfaces. Single spores and spores in short chains are non-motile. Strain YIM $90002^{\top}$ contains meso-diaminopimelic acid, DD-diaminopimelic acid, glycine, lysine and aspartic acid in its cell wall and has glucose, galactose, ribose, xylose, arabinose and mannose as whole-cell sugars (no diagnostic sugars). The phospholipids are phosphatidylglycerol, phosphatidylinositol and phosphatidylethanolamine. The major menaquinones are $\mathrm{MK}-\mathbf{9}\left(\mathrm{H}_{6}\right), \mathrm{MK}-10\left(\mathrm{H}_{2}\right)$ and $\mathrm{MK}-10\left(\mathrm{H}_{4}\right)$. Phylogenetic data indicate that this strain belongs to the family Nocardiopsaceae. The morphological and physiological characteristics and chemotaxonomic and phylogenetic data for this strain differ from those of previously described actinomycetes. Therefore, a new genus,

Streptimonospora, is proposed for this organism; the type species of the genus is Streptimonospora salina gen. nov., sp. nov., and the type strain of $S$. salina is strain YIM $90002^{\top}$.
\end{abstract}

Keywords: Nocardiopsaceae, Streptimonospora salina sp. nov., 16S rDNA

\section{INTRODUCTION}

The family Nocardiopsaceae (Rainey et al., 1996) contains two genera, namely Nocardiopsis (Meyer, 1976) and Thermobifida (Zhang et al., 1998). Although 16S rRNA sequence-based phylogenetic analysis shows that they form a distinct clade in the suborder Streptosporangineae (Stackebrandt et al., 1997), Nocardiopsis and Thermobifida are morphologically and chemotaxonomically different. Currently, the genus Nocardiopsis contains the following validly de-

Abbreviations: DAP, diaminopimelic acid, GL, phospholipids of unknown structure containing glucosamine; ISP, International Streptomyces Project; PC, phosphatidylcholine; PE, phosphatidylethanolamine; PG, phosphatidylglycerol; PI, phosphatidylinositol; PME, phosphatidylmethylethanolamine.

The GenBank accession number for the 16S rDNA sequence of Streptimonospora salina strain YIM $90002^{\top}\left(={\text { CCTCC } 99003^{\top}}^{\top}\right.$ CCRC $\left.16284^{\top}\right)$ is AF178988. scribed species and subspecies: Nocardiopsis dassonvillei, Nocardiopsis alborubida, Nocardiopsis antarctica, Nocardiopsis listeri, Nocardiopsis lucentensis, Nocardiopsis halophila, Nocardiopsis alba subsp. alba, Nocardiopsis alba subsp. prasina and Nocardiopsis synnemataformans (Meyer, 1976; Grund \& Kroppenstedt, 1990; Abyzov et al., 1983; Yassin et al., 1993, 1997; Al-Tai \& Ruan, 1994; Miyashita et al., 1984). The subspecies N. alba subsp. prasina has been elevated to species rank as Nocardiopsis prasina (type strain DSM $43845^{\mathrm{T}}$ ) on the basis of levels of DNA-DNA hybridization $(24.25 \%)$ between $N$. alba subsp. alba and N. alba subsp. prasina (Yassin et al., 1997). Three species, $N$. antarctica, $N$. alborubida and $N$. dassonvillei, were designated as synonyms of $N$. dassonvillei on the basis of both 16S rDNA sequence similarity and DNA-DNA hybridization data (Yassin et al., 1997). The genus Thermobifida includes Thermobifida fusca and Thermobifida alba and both of them were transferred from the genus Thermomonospora (Zhang et al., 
1998). The species Thermomonospora mesouvifomis was proposed to be a synonym of Thermomonospora alba (Zhang et al., 1998; McCarthy \& Cross, 1984).

During our taxonomic studies on extremophilic actinomycetes, we isolated a strain, YIM $90002^{\mathrm{T}}$, from soil samples collected from a salt lake in Xinjiang, the western province of China. After a primary analysis of the 16S rDNA sequence of the strain, together with analysis of the 16S rDNA sequences of many representative species from most genera of actinomycetes in databases, we found high levels of sequence similarity between Nocardiopsis species and Thermobifida species. Strain YIM $90002^{\mathrm{T}}$, however, formed a distinct branch in the phylogenetic tree. This strain was morphologically different from any other species of actinomycete. Therefore, strain YIM $90002^{\mathrm{T}}$ differs phylogenetically and phenotypically from the closest genera, Nocardiopsis and Thermobifida. More detailed analyses were carried out subsequently.

In this work, we have analysed and classified strain YIM $90002^{\mathrm{T}}$ by reconciling the genotypic and phenotypic features (Embley \& Stackebrandt, 1994). We propose that the micro-organism should be included in a new genus, Streptimonospora gen. nov., as Streptimonospora salina sp. nov.

\section{METHODS}

Organism and culture conditions. Strain YIM 90002 ${ }^{\mathrm{T}}$ (as type species of the genus) was isolated from soil samples collected from a salt lake in Xinjiang, China, and deposited in the Chinese Centre for Type Cultures Collection as strain

Table 1 Strains investigated in this study

Nocardiopsis halophila was not included in this study.

\begin{tabular}{|c|c|c|}
\hline Taxon & Strain & $\begin{array}{l}\text { 16S rDNA } \\
\text { accession no. }\end{array}$ \\
\hline Streptimonospora salina & YIM $90002^{\mathrm{T}}$ & AF178988 \\
\hline Thermobifida alba & JCM $3077^{\mathrm{T}}$ & AF002260 \\
\hline Thermobifida fusca & JCM $3262^{\mathrm{T}}$ & AF002264 \\
\hline Thermobifida mesouviformis* & $\mathrm{JCM} 3169^{\mathrm{T}}$ & AF002265 \\
\hline Nocardiopsis prasina & DSM $43845^{\mathrm{T}}$ & X97884 \\
\hline Nocardiopsis listeri & DSM $40297^{\mathrm{T}}$ & X97887 \\
\hline Nocardiopsis alba & DSM $43377^{\mathrm{T}}$ & X97883 \\
\hline Nocardiopsis lucentensis & DSM $44048^{\mathrm{T}}$ & X97888 \\
\hline $\begin{array}{l}\text { Nocardiopsis } \\
\text { synnemataformans }\end{array}$ & DSM $44143^{\mathrm{T}}$ & Y13593 \\
\hline Nocardiopsis dassonvillei & DSM $43111^{\mathrm{T}}$ & X97886 \\
\hline Thermomonospora curvata & IFO $15933^{\mathrm{T}}$ & D86945 \\
\hline Streptosporangium album & DSM $43023^{\mathrm{T}}$ & X89934 \\
\hline Actinomadura madurae & DSM $43067^{\mathrm{T}}$ & X97889 \\
\hline Microtetraspora glauca & DSM $43311^{\mathrm{T}}$ & X93190 \\
\hline Saccharothrix australiensis & NRRL $11239^{\mathrm{T}}$ & AF114803 \\
\hline Streptomyces megasporus & DSM $41476^{\mathrm{T}}$ & Z68100 \\
\hline
\end{tabular}

* Synonym of Thermobifida alba (Zhang et al., 1998).
CCTCC $99003^{\mathrm{T}}$ and the Culture Collection of the Food Industry Research \& Development Institute, Taiwan, as strain CCRC 16284 ${ }^{\mathrm{T}}$. International Streptomyces Project (ISP) medium 5 (salt concentration, $15 \%$, w/v; $\mathrm{pH} 7 \cdot 0$ ) (Shirling \& Gottlieb, 1966) was used for the isolation and pure-culture incubation of strain YIM $90002^{\mathrm{T}}$. Cell material for DNA extraction was grown on ISP medium 5 for YIM $90004^{\mathrm{T}}$ at $28^{\circ} \mathrm{C}$ for $28 \mathrm{~d}$. The wet biomass used for whole-cell analysis of amino acids and sugars was obtained from cultures grown in ISP 5 broth (salt concentration, $15 \%$, w/v) for $28 \mathrm{~d}$ at $28^{\circ} \mathrm{C}$. All strains investigated in this study are listed in Table 1.

Preparation of genomic DNA and amplification of the 16S rRNA gene. Genomic DNA was isolated from the test strain by using a procedure (Hopwood et al., 1985) that was modified slightly by us. 16S rDNA was amplified by PCR using TaKaRa Ex Taq (TaKaRa Biotechnology) and primers A 8-27f (5'-CCGTCGACGAGCTCAGAGTTTGATCCTGGCTCAG-3') and B 1523-1504r (5'-CCCGGGTACCAAGCTTAAGGAGGTGATCCAGCCGCA-3'). The conditions used for thermal cycling were as follows: denaturation at $95^{\circ} \mathrm{C}$ for $5 \mathrm{~min}$, followed by 35 cycles of denaturation at $95^{\circ} \mathrm{C}$ for $1 \mathrm{~min}$, annealing at $56^{\circ} \mathrm{C}$ for $1 \mathrm{~min}$ and extension at $72{ }^{\circ} \mathrm{C}$ for $3 \mathrm{~min}$. At the end of the cycles, the reaction mixture was kept at $72^{\circ} \mathrm{C}$ for $5 \mathrm{~min}$ and then cooled to $4{ }^{\circ} \mathrm{C}$. The $1.5 \mathrm{~kb}$ amplified $16 \mathrm{~S}$ rDNA fragment was separated by agarose gel electrophoresis and purified by using a Watson gel extraction kit. The purified fragment was sequenced directly by using the Big Dye terminator cycle sequencing ready reaction kit (PerkinElmer) and was analysed with an ABI PRISM 377 DNA sequencer. The sequencing primers were KMS098PB1r (5'TAAGGAGGTGATCCAGCC-3'), KMS098PDr (5'-GGGTTGCGCTCGTTG-3') and KMS098PCr (5'-TCTGCGCATTTCACCGCTAC-3').

Sequence alignment and phylogenetic analysis. Reference strains were chosen from BLAST (Altschul et al., 1997) search results. Multiple alignments of sequences determined in this study together with reference sequences obtained from databases and calculations of levels of sequence similarity were carried out using CLUSTAL w 1.74 (Higgins et al., 1992). A phylogenetic tree was reconstructed using the neighbourjoining method of Saitou \& Nei (1987) from $K_{\text {nue }}$ values (Kimura, 1980, 1983). Maximum-likelihood and parsimony trees (not shown) were generated using the treeing algorithms contained in the PHYLIP package (Felsenstein, 1995). The topology of the neighbour-joining phylogenetic tree was evaluated by using the bootstrap resampling method of Felsenstein (1985) with 1000 replicates.

Nucleotide sequence accession numbers. The accession numbers of the reference strains, which are closely related to strain YIM $90002^{\mathrm{T}}$, are listed in Table 1.

Morphological and physiological characteristics. Morphological features were observed on glycerol/asparagine agar (ISP medium 5) (15\% salt, w/v) and the incubation time was 28-30 d at $28^{\circ} \mathrm{C}$. Physiological features were observed on media commonly used for the characterization of Streptomyces species (Shirling \& Gottlieb, 1966). Cultural characteristics were determined after $28-30 \mathrm{~d}$ at $28^{\circ} \mathrm{C}$ by using ISP methods (Shirling \& Gottlieb, 1966). Morphological observations of spores and mycelia were obtained by scanning electron microscopy, as described previously (O'Donnell et al., 1993), with a JEOL model JSM35CF scanning electron microscope. The media and procedures used to examine the physiological features and carbon-source utilization of strain 
YIM $90002^{\mathrm{T}}$ were those described by Shirling \& Gottlieb (1966) and Locci (1989). Colour determinations were made by comparing pure cultures with colour chips from the ISCC-NBS colour charts (standard samples, no. 2106) (Kelly, 1964).

Analysis of chemotaxonomic characteristics. Cell wall was purified and analysed using the TLC protocol of Lechevalier \& Lechevalier (1980). The procedures of Becker et al. (1964) and Lechevalier \& Lechevalier (1980) were used for the analysis of whole-cell composition. GC/MS was used for the quantitative determination of sugar content (Saddler et al., 1991). The phospholipid analysis was carried out by the method of Lechevalier et al. (1981). Menaquinones were determined using the procedures of Collins (1985).

\section{RESULTS}

\section{Morphological observations}

Morphological observation of a 28-d-old culture of strain YIM $90002^{\mathrm{T}}$ grown on glycerol/asparagine agar (ISP medium 5) containing 15\% (w/v) salt revealed that the vegetative hyphae with irregular branches were well developed but not fragmented (Fig. 1). The
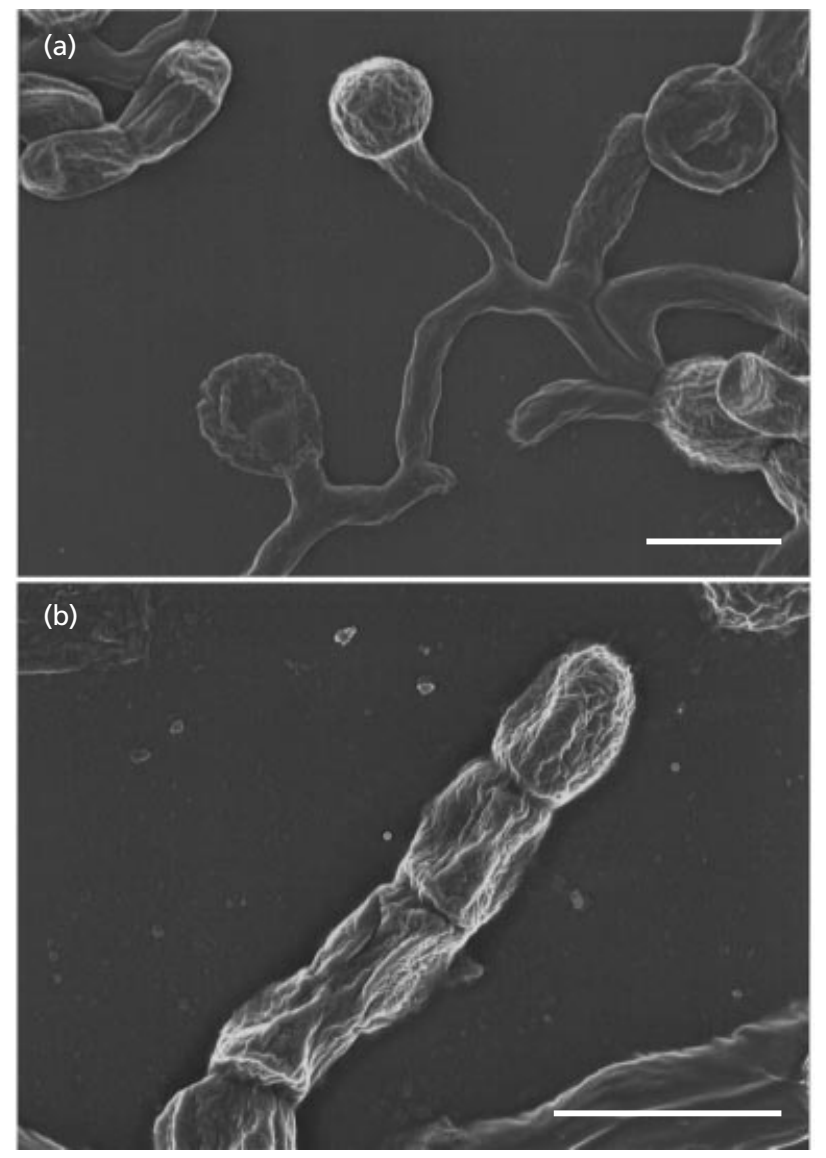

Fig. 1. Scanning electron micrographs of Streptimonospora salina (YIM $90002^{\top}$ ) grown on ISP medium 5 for $28 \mathrm{~d}$ at $28^{\circ} \mathrm{C}$, showing single spores (a) and a short chain of spores (b). Bars, $2 \mu \mathrm{m}$. aerial mycelium, at maturity, formed short chains of spores; spores in short chains were oval- to rod-shaped $(1 \cdot 5-2 \times 1 \mu \mathrm{m})$ with wrinkled surfaces (Fig. 1b). Substrate mycelium was extensively branched with nonfragmenting hyphae. Single spores, oval to round and $1.4-1.6 \mu \mathrm{m}$ in diameter, were borne on sporophores of substrate mycelium (Fig. 1a) or dichotomously branched sporophores, and the surfaces of single spores were wrinkled. Therefore, the spores consist of two types, both of which are non-motile.

\section{Cultural characteristics}

As shown in Table 2, strain YIM 90002 $2^{\mathrm{T}}$ produced well-developed white to pale-yellow colonies on most media tested. It showed good growth on most media except oatmeal agar (ISP medium 3). No diffusible pigments were produced. It developed aerial hyphae on most media tested, especially Czapek's agar and glycerol/asparagine agar (ISP medium 5).

\section{Physiological characteristics}

Strain YIM 90002 ${ }^{\mathrm{T}}$ utilized glucose, sucrose, maltose, arabinose, raffinose, starch, glycerol, mannitol and histidine. It was positive for starch hydrolysis and melanin production, but negative for milk coagulation, milk peptonization, growth in cellulose, $\mathrm{H}_{2} \mathrm{~S}$ production and gelatin liquefaction.

\section{Chemotaxonomic characteristics}

The cell-wall amino acid composition and whole-cell sugar pattern of strain YIM $90002^{\mathrm{T}}$ are shown in Table 3. The cell walls contained meso-diaminopimelic acid (DAP), glycine, aspartic acid and lysine and trace amounts of DD-DAP. Whole cells of strain YIM $90002^{\mathrm{T}}$ contained large amounts of glucose and galactose and smaller amounts of ribose, arabinose, xylose and mannose. Rhamnose and madurose were not detected, indicating that the strain contains no characteristic wall sugars (according to the scheme of Lechevalier \& Lechevalier, 1980). The phospholipids are phosphatidylglycerol (PG), phosphatidylinositol (PI) and phosphatidylethanolamine (PE). The major menaquinones are $\mathrm{MK}-9\left(\mathrm{H}_{6}\right), \mathrm{MK}-10\left(\mathrm{H}_{2}\right)$ and $\mathrm{MK}$ $10\left(\mathrm{H}_{4}\right)$.

\section{Phylogenetic position}

An almost complete $16 \mathrm{~S}$ rDNA sequence was determined for strain YIM $90002^{\mathrm{T}}(>95 \%$ of the Escherichia coli sequence) from position 8 to position 1523 (E. coli numbering system; Brosius et al., 1978). BLAST search results for strain YIM 90002 ${ }^{\mathrm{T}}$ came from non-redundant GenBank $+\mathrm{EMBL}+\mathrm{DDBJ}+\mathrm{PDB}$; when reference sequences were chosen, unidentified and unpublished sequences were excluded (Table 1). The number of nucleotides compared was 1436 after elimination of sites for which the nucleotides were not 
Table 2 Cultural characteristics of strain YIM $90002^{\top}$

Diffusible pigments were not produced on any of the media listed.

\begin{tabular}{|lcccc|}
\hline Medium* & Growth & Sporulation & & Colour of colonies广 \\
\cline { 3 - 5 } & & & Aerial mycelium & Substrate mycelium \\
\hline Yeast extract/malt extract (ISP medium 2) & Good & Moderate & Pale white & Mid-yellow \\
Oatmeal agar (ISP medium 3) & Poor & Poor & White & Deep yellow \\
Inorganic salt/starch agar (ISP medium 4) & Moderate & Moderate & White & Yellow/white \\
Glycerol/asparagine (ISP medium 5) & Good & Good & White & Mid-yellow \\
Czapek's agar & Good & Good & White & Mid-yellow \\
Potato agar & Good & Moderate & White & Deep yellow \\
Nutrient agar & Good & Moderate & White & Deep orange/yellow \\
\hline
\end{tabular}

* Containing $15 \%(\mathrm{w} / \mathrm{v})$ salt; $\mathrm{pH} 7 \cdot 0$.

$\dagger$ Colours taken from ISCC-NBS colour charts (standard samples, no. 2106) (Kelly, 1964).

Table 3 Chemotaxonomic characteristics of strain YIM $90002^{\top}$ and the genera of the Nocardiopsaceae

The genera Nocardiopsis and Thermobifida follow the classification of Zhang et al. (1998). None of the taxa exhibited any diagnostic sugars. Abbreviations: DAP, diaminopimelic acid; GL, phospholipids of unknown structure containing glucosamine; PC, phosphatidylcholine; PE, phosphatidylethanolamine; PG, phosphatidylglycerol; PI, phosphatidylinositol; PME, phosphatidylmethylethanolamine.

\begin{tabular}{|c|c|c|c|}
\hline Characteristic & Strain YIM $90002^{\mathrm{T}}$ & Nocardiopsis & Thermobifida \\
\hline Sugar content & $\begin{array}{l}15 \% \text { Ribose, } 6 \% \text { xylose, } 5 \% \text { arabinose, } \\
2 \% \text { mannose, } 34 \% \text { galactose, } 38 \% \text { glucose* }\end{array}$ & Type C & Type C \\
\hline Wall peptidoglycan & $\begin{array}{l}\text { meso-DAP [glycine, lysine and aspartic } \\
\text { acid (detected), DD-DAP (trace)] }\end{array}$ & $\begin{array}{l}\text { Cell wall type III } \\
\text { (meso-DAP) }\end{array}$ & $\begin{array}{l}\text { Cell wall type III [meso-DAP, } \\
\text { LL-DAP (trace)] }\end{array}$ \\
\hline Phospholipids & PI, PE, PG & Type PIII (PC, PME, GL) & Type PII (PE, PME, GL) \\
\hline Menaquinones & MK-9 $\left(\mathrm{H}_{6}\right)$, MK-10( $\left.\mathrm{H}_{2}\right)$, MK-10( $\left.\mathrm{H}_{4}\right)$ & $\begin{array}{l}\text { Type } 4 \mathrm{c}\left[\mathrm{MK}-10\left(\mathrm{H}_{2}\right)\right. \\
\left.\left.\text { MK-10( } \mathrm{H}_{4}\right), \mathrm{MK}-10\left(\mathrm{H}_{6}\right)\right]\end{array}$ & $\begin{array}{l}\text { Type } 4 \mathrm{~d}\left[\mathrm{MK}-10\left(\mathrm{H}_{6}\right)\right. \\
\left.\left.\text { MK-10( } \mathrm{H}_{8}\right), \mathrm{MK}-11\left(\mathrm{H}_{6}\right)\right]\end{array}$ \\
\hline
\end{tabular}

* Relative content. Rhamnose and madurose were not detected.

determined in all sequences. The BLAST search results and the phylogenetic tree (Fig. 2) generated from representative strains of the related genera showed that strain YIM $90002^{\mathrm{T}}$ had high levels of sequence similarity to species of Thermobifida (Zhang et al., 1998) and members of the genus Nocardiopsis. The phylogenetic tree obtained by applying the neighbourjoining method to $K_{\text {nuc }}$ values is shown in Fig. 2. $16 \mathrm{~S}$ rDNA analysis revealed that strain YIM $90002^{\mathrm{T}}$ is phylogenetically closely related to members of the genera Nocardiopsis and Thermobifida (the sequence similarity levels were $94 \cdot 9-95 \cdot 1 \%$ to Thermobifida and $93 \cdot 7-94.7 \%$ to Nocardiopsis). All strains of the genera Nocardiopsis and Thermobifida, together with strain YIM $90002^{\mathrm{T}}$, formed a distinct clade that was strongly supported by a high bootstrap value $(100 \%)$. Phylogenetically, strain YIM $90002^{\mathrm{T}}$ forms a branch that is distinct from the groups containing the genera Nocardiopsis and Thermobifida and which lies between the two groups.

\section{DISCUSSION}

The results of $16 \mathrm{~S}$ rDNA sequence comparisons clearly demonstrated that strain YIM $90002^{\mathrm{T}}$ is a member of the family Nocardiopsaceae, and the 16S rDNA sequence of strain YIM $90002^{\mathrm{T}}$ contains all the signature nucleotides defined for the family Nocardiopsaceae, as described by Stackebrandt et al. (1997). The high levels of $16 \mathrm{~S}$ rDNA sequence similarity to species of the genera Nocardiopsis (93.7-94.7\%) and Thermobifida $(94 \cdot 9-95 \cdot 1 \%)$ place strain YIM $90002^{\mathrm{T}}$ in the Nocardiopsaceae as a distinct member between Nocardiopsis and Thermobifida (Fig. 2).

Strain YIM $90002^{\mathrm{T}}$ is morphologically different from members of the genera Thermobifida and Nocardiopsis. On aerial mycelium, strain YIM $90002^{\mathrm{T}}$ forms short chains of spores that are somewhat like the spores formed on aerial mycelium by members of Nocardiopsis. Strain YIM $90002^{\mathrm{T}}$ also forms single spores, borne on sporophores or dichotomously branched 


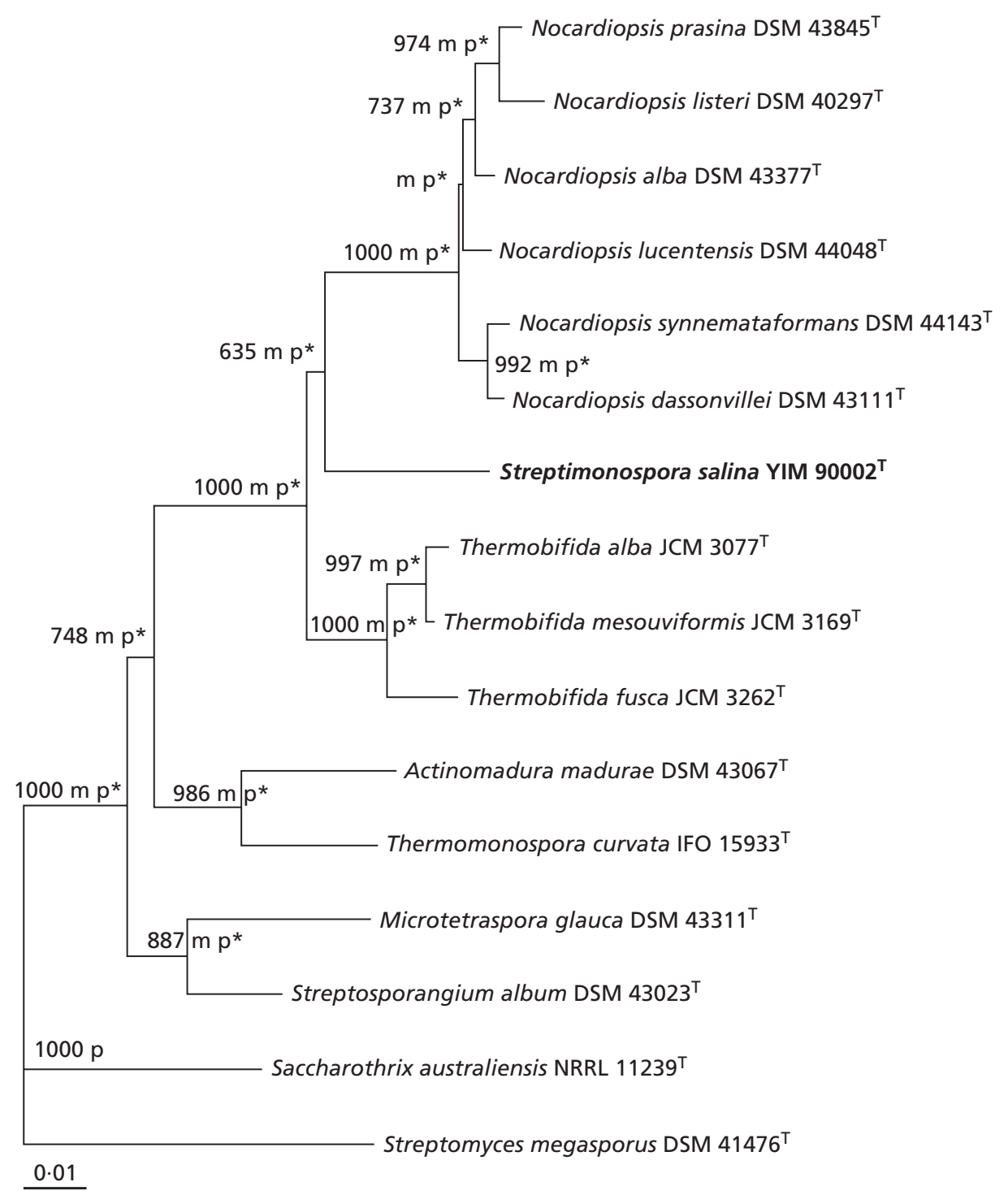

Fig. 2. Neighbour-joining tree showing the phylogenetic relationships among Streptimonospora salina and representative members of the families Nocardiopsaceae, Streptosporangiaceae and Thermomonosporaceae in the suborder Streptosporangineae. Streptomyces megasporum was used as the outgroup. The ' $m$ ' and ' $p$ ' labels indicate branches that were also found with the maximum-likelihood (Felsenstein, 1981) and parsimony (Kluge \& Farris, 1969) algorithms, respectively: asterisks indicate branches that were recovered with all three methods. The analysis included 1436 unambiguous nucleotide positions. Bootstrap values (>50\%) from 1000 analyses are shown at the nodes of the tree. The strain shown in bold is the type species of the new genus Streptimonospora. Bar, 1 nucleotide substitution per 100 nucleotides of $16 \mathrm{~S}$ rDNA sequence.

sporophores of substrate hyphae, that are morphologically similar to the spores found on dichotomously branched sporophores (resulting in spore clusters on aerial hyphae) of members of the genus Thermobifida.

Strain YIM $90002^{\mathrm{T}}$ is chemotaxonomically different from members of the genera Nocardiopsis and Thermobifida. The cell wall of strain YIM $90002^{\mathrm{T}}$ contains meso-DAP, DD-DAP, glycine and aspartic acid ; wholecell hydrolysates contain no diagnostic sugars; the phospholipids are PG, PI and PE and the major menaquinones are MK-9 $\left(\mathrm{H}_{6}\right), \mathrm{MK}-10\left(\mathrm{H}_{2}\right)$ and MK$10\left(\mathrm{H}_{4}\right)$. For members of the genus Thermobifida, cell walls contain meso-DAP (cell wall type III), a trace amount of LL-DAP may be detected in whole-cell hydrolysates, the sugar pattern is type $\mathrm{C}$ (no diagnostic sugars), the predominant menaquinones are $\mathrm{MK}$ $10\left(\mathrm{H}_{6}\right)$, MK-10( $\left.\mathrm{H}_{8}\right)$ and MK-11( $\left.\mathrm{H}_{6}\right)$ and the phospholipid pattern is type II [PE, PME (phosphatidylmethylethanolamine), GL (phospholipids of unknown structure, containing glucosamine)] (Zhang et al., 1998). For members of the genus Nocardiopsis, the peptidoglycan contains meso-DAP, no diagnostic sugars are present (cell wall chemotype III/C) (Lechevalier \& Lechevalier, 1970), the phospholipid pattern is type III (phosphatidylcholine, PME, GL) 
and the menaquinone pattern is type $4 \mathrm{c}\left[\mathrm{MK}-10\left(\mathrm{H}_{2}\right)\right.$, MK-10 $\left(\mathrm{H}_{4}\right)$ and MK-10( $\left.\mathrm{H}_{6}\right)$ ] (Zhang et al., 1998).

Therefore, we propose that strain YIM $90002^{\mathrm{T}}$ should be classified as a member of a new genus, Streptimonospora. The type species is Streptimonospora salina gen. nov., sp. nov.

\section{Description of Streptimonospora gen. nov.}

Streptimonospora (Strep.ti.mo.no.spo'ra. Gr. adj. streptos pliant, bent; Gr. adj. monos single, solitary; Gr. fem. n. spora a seed, spore; M.L. fem. n. Streptimonospora indicating that this organism forms two types of spore, with wrinkled surfaces, on aerial mycelium and substrate mycelium).

Gram-positive, aerobic organisms with branching hyphae. Non-fragmenting substrate mycelia are present. The aerial mycelium, at maturity, forms short chains of spores; the spores in short chains are oval- to rod-shaped $(1.5-2 \times 1 \mu \mathrm{m})$ with wrinkled surfaces. Substrate mycelium is extensively branched with nonfragmenting hyphae. Single spores, which are oval to round $(1.4-1.6 \mu \mathrm{m})$, are borne on sporophores or dichotomously branched sporophores of substrate hyphae; the surfaces of the spores are wrinkled. Both types of spore are non-motile. The cell wall contains meso-DAP, DD-DAP, glycine and aspartic acid. Whole-cell hydrolysates contain large amounts of glucose and galactose and smaller amounts of ribose, arabinose, xylose and mannose. The phospholipids are phosphatidylglycerol, phosphatidylinositol and phosphatidylethanolamine. The major menaquinones are MK-9 $\left(\mathrm{H}_{6}\right)$, MK-10 $\left(\mathrm{H}_{2}\right)$ and MK-10( $\left.\mathrm{H}_{4}\right)$. The type species is Streptimonospora salina.

\section{Description of Streptimonospora salina sp. nov.}

Streptimonospora salina (sa.li'na. L. adj. salina salted, saline).

Aerial mycelium is well developed but not fragmented. Colonies are white on most media. Two types of spore with wrinkled surfaces are borne on aerial mycelium and substrate mycelium. No diffusible pigment is produced, but melanin is produced. Utilizes glucose, sucrose, maltose, arabinose, raffinose, starch, glycerol, mannitol and histidine. Positive for starch hydrolysis and melanin production, but negative for milk coagulation, milk peptonization, growth in cellulose, $\mathrm{H}_{2} \mathrm{~S}$ production and gelatin liquefaction. Optimum growth occurs in media supplemented with salt at a concentration of $15 \%(\mathrm{w} / \mathrm{v})$ at $28{ }^{\circ} \mathrm{C}$ and $\mathrm{pH} 7 \cdot 0$.

Isolated from hypersaline habitats (a salt lake in China). The type strain is strain YIM $90002^{\mathrm{T}}$ (= CCTCC $99003^{\mathrm{T}}=$ CCRC $16284^{\mathrm{T}}$ ).

\section{ACKNOWLEDGEMENTS}

This research was supported by National Natural Science Foundation of China and the International Science Cooperation Foundation of Yunnan.

\section{REFERENCES}

Abyzov, S. S., Philipova, S. N. \& Kuznetsov, V. D. (1983). Nocardiopsis antarcticus, a new species of actinomycetes, isolated from the ice sheet of the central Antarctic glacier. Izv Akad Nauk SSSR Ser Biol 4, 559-568.

Al-Tai, A. M. \& Ruan, J.-S. (1994). Nocardiopsis halophila sp. nov., a new halophilic actinomycete isolated from soil. Int J Syst Bacteriol 44, 474-478.

Altschul, S. F., Madden, T. L., Schäffer, A. A., Zhang, J., Zhang, Z., Miller, W. \& Lipman, D. J. (1997). Gapped BLAST and PSI-BLAST: a new generation of protein database search programs. Nucleic Acids Res 25, 3389-3402.

Becker, B., Gordon, R. E., Lechevalier, H. A. \& Lechevalier, M. P. (1964). Rapid differentiation between Nocardia and Streptomyces by paper chromatography of whole cell hydrolysates. Appl Microbiol 12, 421-423.

Brosius, J., Palmer, M. L., Kennedy, P. J. \& Noller, H. F. (1978). Complete nucleotide sequence of a $16 \mathrm{~S}$ ribosomal RNA gene from Escherichia coli. Proc Natl Acad Sci U S A 75, 4801-4805.

Collins, M. D. (1985). Isoprenoid quinone analysis in bacterial classification and identification. In Chemical Methods in Bacterial Systematics, pp. 267-287. Edited by M. Goodfellow \& D. E. Minnikin. London: Academic Press.

Embley, T. M. \& Stackebrandt, E. (1994). The molecular phylogeny and systematics of the actinomycetes. Annu Rev Microbiol 48, 257-289.

Felsenstein, J. (1981). Evolutionary trees from DNA sequences: a maximum likelihood approach. J Mol Evol 17, 368-376.

Felsenstein, J. (1985). Confidence limits on phylogenies: an approach using the bootstrap. Evolution 39, 783-789.

Felsenstein, J. (1995). PHYLIP (phylogenetic inference package) version 3.57c. Department of Genetics, University of Washington, Seattle, WA, USA.

Grund, E. \& Kroppenstedt, R. M. (1990). Chemotaxonomy and numerical taxonomy of the genus Nocardiopsis Meyer 1976. Int J Syst Bacteriol 40, 5-11.

Higgins, D. G., Bleasby, A. J. \& Fuchs, R. (1992). CLUSTAL V: improved software for multiple sequence alignment. Comput Appl Biosci 8, 189-191.

Hopwood, D. A., Bibb, M. J., Chater, K. F., Kieser, T., Bruton, C. J., Kieser, H. M., Lydiate, D. J., Smith, C. P. \& Ward, J. M. (1985). Genetic manipulation of Streptomyces - a laboratory manual. In Preparation of Chromosomal, Plasmid and Phage DNA, pp. 79-80. Norwich: F. Crowe \& Sons.

Kelly, K. L. (1964). Color-name Charts Illustrated with Centroid Colors. Inter-Society Color Council, National Bureau of Standards.

Kimura, M. (1980). A simple method for estimating evolutionary rates of base substitutions through comparative studies of nucleotide sequences. $J$ Mol Evol 16, 111-120.

Kimura, M. (1983). The Neutral Theory of Molecular Evolution. Cambridge: Cambridge University Press.

Kluge, A. G. \& Farris, F. S. (1969). Quantitative phyletics and the evolution of anurans. Syst Zool 18, 1-32.

Lechevalier, H. A. \& Lechevalier, M. P. (1970). A critical evolution of the genera of aerobic actinomycetes. In The Actinomycetes, pp. 393-405. Edited by H. Prauser. Jena: Gustav Fischer.

Lechevalier, M. P. \& Lechevalier, H. A. (1980). The chemotaxonomy of actinomycetes. In Actinomycete Taxonomy, pp. 
227-291. Edited by A. Dietz \& D. W. Thayer. Arlington, VA: Society for Industrial Microbiology.

Lechevalier, M. P., Stern, A. E. \& Lechevalier, H. A. (1981). Phospholipids in the taxonomy of actinomycetes. In Actinomycetes, pp. 11-116. Edited by K. P. Schaal \& G. Pulverer. New York: Gustav Fischer.

Locci, R. (1989). Streptomycetes and related genera. In Bergey's Manual of Systematic Bacteriology, vol. 4, pp. 2451-2508. Edited by S. T. Williams, M. E. Sharpe \& J. G. Holt. Baltimore: Williams \& Wilkins.

McCarthy, A. J. \& Cross, T. (1984). A taxonomic study of Thermomonospora and other monosporic actinomycetes. J Gen Microbiol 130, 5-25.

Meyer, J. (1976). Nocardiopsis, a new genus of the order Actinomycetales. Int J Syst Bacteriol 26, 487-493.

Miyashita, K., Mikami, Y. \& Arai, T. (1984). Alkalophilic actinomycete, Nocardiopsis dassonvillei subsp. prasina subsp. nov., isolated from soil. Int J Syst Bacteriol 34, 405-409.

O'Donnell, A. G., Falconer, C., Goodfellow, M., Ward, A. C. \& Williams, E. (1993). Biosystematics and diversity amongst novel carboxydotrophic actinomycetes. Antonie Leeuwenhoek 64, 325-340.

Rainey, F. A., Ward-Rainey, N., Kroppenstedt, R. M. \& Stackebrandt, E. (1996). The genus Norcardiopsis represents a phylogenetically coherent taxon and a distinct actinomycete lineage: proposal of Nocardiopsaceae fam. nov. Int J Syst Bacteriol 46, $1088-1092$.
Saddler, G. S., Tavecchia, P., Lociuro, S., Zanol, M., Colombo, L. \& Selva, E. (1991). Analysis of madurose and other actinomycete whole cell sugars by gas chromatography. J Microbiol Methods 14, 185-191.

Saitou, N. \& Nei, M. (1987). The neighbor-joining method: a new method for reconstructing phylogenetic trees. Mol Biol Evol 4, 406-425.

Shirling, E. B. \& Gottlieb, D. (1966). Methods for characterization of Streptomyces species. Int J Syst Bacteriol 16, 313-340.

Stackebrandt, E., Rainey, F. A. \& Ward-Rainey, N. L. (1997). Proposal for a new hierarchic classification system, Actinobacteria classis nov. Int J Syst Bacteriol 47, 479-491.

Yassin, A. F., Galinski, E. A., Wohlfarth, A., Jahnke, K.-D., Schaal, K. P. \& Trüper, H. G. (1993). A new actinomycete species, Nocardiopsis lucentensis sp. nov. Int J Syst Bacteriol 43, 266-271.

Yassin, A. F., Rainey, F. A., Burghardt, J., Gierth, D., Ungerechts, J., Lux, I., Seifert, P., Bal, C. \& Schaal, K. P. (1997). Description of Nocardiopsis synnemataformans sp. nov., elevation of Nocardiopsis alba subsp. prasina to Nocardiopsis prasina comb. nov., and designation of Nocardiopsis antarctica and Nocardiopsis alborubida as later subjective synonyms of Nocardiopsis dassonvillei. Int J Syst Bacteriol 47, 983-988.

Zhang, Z., Wang, Y. \& Ruan, J. (1998). Reclassification of Thermomonospora and Microtetraspora. Int J Syst Bacteriol 48, 411-422. 